\title{
Pääkirjoitus
}

\author{
Anneli Lehtisalo
}

\section{Kuka kaipaa tiedeyhteisöä?}

Puolentoista vuoden koronaeristys ja etätyöt ovat saaneet monet kaipaamaan työyhteisöään, kahvihuonekeskusteluja, käytäväideointia ja kasvokkaista yhdessä tekemistä. Arkisten kohtaamisten lisäksi myös laajemmat tutkijoiden tapaamiset ovat muuttuneet virtuaalisiksi. Median ja viestinnän tutkimuksen päivät 2020 siirtyivät nekin verkkoon, kun niitä ensin lykättiin toiveikkaana seuraavaan vuoteen. Sinänsä verkkokonferensseja voi pitää varsin kätevinä, jos kesken työpäivän voi piipahtaa toisella puolen maapalloa järjestettävässä tapahtumassa ilman matkan kuormitusta ympäristölle ja itselle. Ne eivät kuitenkaan tarjoa samalla tavalla mahdollisuuksia uusiin kontakteihin ja epävirallisiin keskusteluihin. Ajattelun vire ja työn imu edellyttävät myös ihmisten kohtaamista.

Mutta kaipaako kukaan tiedeyhteisöä? Tarkoitan tällä sitä osin kuvitteellista muodostelmaa, tieteenalakohtaista yhteisöä, "johon kuuluvat henkilöt tekevät tieteellistä tutkimusta sekä osallistuvat tieteelliseen keskusteluun ja vertaisarviointiin" (Tieteen termipankki 2018). Tämä tuli mieleeni, kun jälleen kerran kuulin, kuinka Media- ja viestintätieteellisen seuran Mevi ry:n jäsenmäärä on jatkanut laskuaan. Vuonna 2006 henkilöjäseniä oli vielä ollut hiukan päälle viisi sataa, mutta nyt vain puolet tästä. Jäsenkato on ollut suoraviivainen trendi, johon kertaluontoisen katkoksen on tuonut vain jäsenmaksun kytkeminen Mevi-päivien osallistumismaksuun. Selitys ja syyllinen on löydetty: avoin julkaiseminen. Kun seuran jäsenyys ei enää takaa tilattavan lehden kaltaisia etuja vaan artikkelit voi ladata ilmaiseksi, ei seuran jäsenyyskään "kannata".

Avoin julkaiseminen on johtanut Suomen oloissa ristiriitaiseen tilanteeseen. Periaatteessa monikaan tutkija ei vastustane avointa tiedettä. Avoimena tutkimustulokset leviävät helpommin, niihin viitataan enemmän (Piwowar ym. 2018), myös vähävaraisilla organisaatioilla on pääsy tiedon lähteille ja digitaalisia julkaisuja on helppo hyödyntää esimerkiksi opetuksessa. Suurilla kielialueilla avoimen tieteen käytännöillä voidaan vastustaa kaupallisten tieteellisten kustantajien valtaa. Suomessa sen sijaan avoin julkaiseminen uhkaa tieteellisten seurojen olemassaoloa, sillä täällä ne ovat perinteisesti vastanneet tieteellisestä julkaisemisesta. Työn kannustimena ei ole ollut taloudellinen voitto, vaan julkaisuista tulleet tulot on käytetty perustoiminnan ylläpitämiseen. Avoimuuden myötä tulot ovat kadonneet eikä kukaan tunnu haluavan rahoittaa seurojen julkaisutoimintaa (epäonnistuneesta Kotilava-projektista ks. Suomen tiedekustantajien liitto 2020). 
Tiedeyhteisö on osin kuvitteellinen rakennelma, mutta sitä edustaa konkreettinen, elävä toimija, tieteellinen seura jäsenineen. Yleinen haluttomuus osallistua seurojen toimintaan johtaa ikävään päätelmään. Onko tutkijakunta jo niin akateemisen kapitalismin (Kaidesoja ja Kauppinen 2018) kyllästämä, että se näkee tiedon ostettavana tuotteena, jota joku ulkopuolinen järjestelmä tuottaa, ja jos tuon tuotteen saa markkinoilta ilmaiseksi, niin ei tarvitse välittää, mikä se järjestelmä on? Onko tiedeyhteisö muuntautunut toisaalta järjestelmästä vieraantuneeksi, tietoa suoltavaksi tuottajajoukoksi, toisaalta tiedon kuluttajakunnaksi?

Sheila Slaughterin ja Larry Leslien 1990-luvulla kehittämä akateemisen kapitalismin käsite kuvaa sitä, miten yliopistojen toimintaa ohjaa yhä enemmän markkinakäyttäytyminen ja markkinalogiikka. Sen myötä tutkimustiedosta tulee kauppatavaraa ja edelleen kehiteltäviä tuotteita ja yliopistotoimijoista keskenään kilpailevia tulosyksiköitä. (Kaidesoja ja Kauppinen 2018, 98, 102.) Slaughter on myöhemmissä tutkimuksissaan yhdessä Gary Rhoadesin kanssa esitellyt teorian kahdesta eri tietojärjestelmästä. Toinen, akateemisen kapitalismin tietojärjestelmä, noudattaa markkinalogiikkaa ja toinen, julkishyödykkeen tietojärjestelmä, perustuu tietoon julkisena, kaikille vapaana hyödykkeenä. Puhtaassa muodossa järjestelmiä ei ole olemassa, vaan ne elävät rinnakkain. (Kaidesoja ja Kauppinen 2021, 100-102, alun perin Slaughter ja Rhodes 2004.)

Järjestelmät ovat tunnistettavia suomalaisessakin yliopistomaailmassa. Vaikka avoimesta julkaisemisesta on tehty kilpailun väline, kun se on kytketty yliopistojen tulostavoitteisiin, optimistisesti haluan nähdä sen edustavan julkishyödykkeen tietojärjestelmää. Se on keino, jolla tutkimustietoa tarjotaan vapaasti kaikkien hyödynnettäväksi ja vaikkapa ei-hyödynnettäväksi, silkaksi sivistyksen iloksi (vrt. Kaidesoja ja Kauppinen 2018 , 101). Mutta voisiko tieteelliset seuratkin nähdä osana julkishyödykkeen tietojärjestelmää? Seurat eivät olisikaan ulkopuolinen, tuotantokilpailun osapuoli, vaan meistä muotoutuva tiedeyhteisö, joka haluaa toimia yhdessä, tehdä tieteellistä tutkimusta sekä osallistua yhdessä "tieteelliseen keskusteluun ja vertaisarviointiin" (Tieteen termipankki 2018).

Puhe tieteellisestä seurasta, joka toimii toisen logiikan kuin markkinalogiikan mukaan, voi kuulostaa nykyisessä resurssikurimuksessa idealistiselta. Mutta eivätkö tieteelliset seurat jo nykyään saa voimansa tieteelle omistautuneiden vapaaehtoisten työstä? Tämän vuoden Media \& viestintä -lehteen on tarvittu 62 kirjoittajan ja kolmen vierailevan toimittajan sekä ainakin 36 arvioijan ja 14 toimituskuntalaisen aktiivista työpanosta (ks. myös Mäenpää 2020, i). Samalla vapaaehtoisuuden logiikalla Mevin piirissä työstetään parhaillaan ensi vuoden Median ja viestinnän tutkimuksen päiviä ja mukana ollaan myös laajalle yleisölle suunnatussa, Tutkimuskeskus Cometin organisoimassa Mediakritiikin iltapäivässä. Tämä muistuttaa enemmän julkishyödykkeen tietojärjestelmää kuin akateemista kapitalismia.

Vapaan tieteen logiikalla toimivia tiedeyhteisöjä tarvitaan, tai tarkemmin sanottuna, tiedeyhteisö tarvitsee tieteellisten seurojen kaltaisia ryhmittymiä, jotka voivat itse määrittää omaa toimintaansa. Erkki Karvonen (2014) tarkasteli seitsemisen vuotta sitten, millainen on viestinnän tutkijoiden tieteellinen kulttuuri. Katsauksessaan hän päätyi siihen, että viestinnän tutkimus on niin kutsuttu pehmeä tieteenala, joka on moniparadigmaattista ja usein kontekstisidonnaista. Tämä tarkoittaa sitä, että alalla on monia hyväksyttyjä tieteen tekemisen tapoja ja että tutkimuskohteet ja -tulokset ovat monesti paikka- tai kulttuurisidonnaisia. (Emt., 143-144.) Karvosen havainnot osoittavat, että tarvitaan paikalliseen tutkimuskontekstiin erikoistuneita, paikallisella kielellä toimivia 
tiedeyhteisöjä ja tieteellisiä seuroja. Tämä mahdollistaa syvemmälle menevän keskustelun, kun huomiota ei tarvitse kiinnittää suomalaisen yhteiskunnan perusteiden esitteIyyn (vrt. Delamont 2011). Suomen kielellä käytävä tieteellinen keskustelu tukee tieteen kehitystä suomeksi, ja samalla entistä laajemman joukon, kuten opintojen alussa olevien opiskelijoiden tai ammattikentän, on mahdollista ymmärtää keskustelua ja osallistua siihen (Pölönen ym. 2021).

Moni asia lienee muuttunut seitsemässä vuodessa. Monille kansainvälinen tiedeyhteisö saattaa olla merkityksellisin viiteryhmä (vrt. Pölönen ym. 2021, 586), tai tieteidenvälisyyden vaatimuksen yleistyessä naapuritieteenalan tieteellinen keskustelu voikin olla oman työn kannalta tähdellisempää kuin oman tieteenalan keskustelu. Mutta aika ei ole muuttanut Erkki Karvosen tekemän viestinnän tieteenalakulttuurin luonnehdinnan perusajatusta, viestinnän tutkimuksessa kaivataan yhä edelleen moninaisia tieteen tekemisen tapoja ja moninaisia tiedeyhteisöjä.

Media- ja viestintätieteellisen seuran Mevin toiminnasta voi lukea lisää seuran verkkosivuilta (https://mediaviestinta.fi/). Seuraavat Median ja viestinnän tutkimuksen päivät järjestetään Turussa 22.-23.4.2021. Tervetuloa mukaan!

Median \& viestinnän päätoimittajat Jenni Mäenpää ja Anneli Lehtisalo sekä toimitussihteeri Auli Harju kiittävät kirjoittajakuntaa, arvioitsijoita ja toimituskuntaa heidän työpanoksestaan ja siirtyvät seuran rivijäseniksi. Vuoden 2022 alusta päätoimittajina aloittavat apulaisprofessori Mats Bergman (HY/SSKH) ja yliopistonlehtori Saila Poutiainen (HY) sekä uutena toimitussihteerinä väitöskirjatutkija Niina Oisalo (TY).

\section{Kirjallisuus}

Delamont, Sara. 2011. "Academic writing in a global context: the politics and practices of publishing in English." Kirja-arvio. Studies in Higher Education 36 (4): 505-506. https://doi.org/10.1080/03075079.2011.586505.

Kaidesoja, Tuukka ja Ilkka Kauppinen. 2018. "Akateeminen kapitalismi nykyisessä tiedepolitiikassa." Tiede \& edistys 43 (2): 95-123. https://doi.org/10.51809/te.105282.

Karvonen, Erkki. 2014. "Viestinnän tutkimuksen akateeminen heimokulttuuri." Media \& viestintä 37 (2): 141-146. https://iournal.fi/mediaviestinta/article/view/62855.

Mäenpää, Jenni. 2020. "Tieteen talkoolaiset." Media \& viestintä 43 (1): i-iii. https://journal.fi/mediaviestinta/article/view/91077.

Piwowar, Heather, Jason Priem, Vincent Larivière, Juan Pablo Alperin, Lisa Matthias, Bree Norlander, Ashley Farley, Jevin West ja Stefanie Haustein. 2018. "The state of OA: a large-scale analysis of the prevalence and impact of Open Access articles". PeerJ (6): e4375 https://doi.org/10.7717/peeri.4375.

Pölönen, Janne, Sami Syrjämäki, Antti-Jussi Nygård ja Björn Hammarfelt. 2021. Who are the users of national open access journals? The case of the Finnish Journal.fi platform. Learned Publishing 34 (4): 585-592. https://doi.org/10.1002/leap.1405.

Suomen tiedekustantajien liitto. 2020. "Tiedekustantajat ja TSV vastasivat UNIFI:n ja kumppaneiden vetoomukseen." Luettu 21.11.2021. https://tiedekustantajat.fi/edunvalvonta/tiedekustantajat-ja-tsv-vastasivat-unifin-ja-kumppaneiden-vetoomukseen/.

Tieteen termipankki. 2018. "Tiedeyhteisö." Luettu 21.11.2021. https://www.tieteentermipankki.fi/wiki/Nimitys:tiedeyhteisö. 